\title{
A crônica esportiva como missão: José Lins do Rego, a construção do Maracanã e o significado da Copa do Mundo de 1950
}

\author{
Sports chronicle as a mission: José Lins do Rego, the construction of \\ Maracanã, and the meaning of the 1950 FIFA World Cup
}

\author{
Bernardo Borges Buarque de Hollanda \\ Fundação Getúlio Vargas, Rio de Janeiro / Brasil \\ Doutor em História Social da Cultura, PUC-Rio \\ bernardobuarque@gmail.com \\ Leandro Martan Bezerra Santos \\ Fundação Getúlio Vargas, Rio de Janeiro / Brasil \\ Graduando em Ciências Sociais, FGV-RJ
}

\begin{abstract}
Resumo: 0 artigo revisita o significado da Copa do Mundo de 1950 para o Brasil, à luz de uma série de crônicas esportivas do escritor José Lins do Rego, publicadas no Jornal dos Sports, entre 1946 e 1950. 0 argumento procura demonstrar os pressupostos e as motivações que levaram o romancista paraibano a se engajar, por meio de sua coluna diária "Esporte e Vida", na campanha em prol do Mundial de 1950. Tal engajamento esteve longe de ser uma postura isolada e compartilhou a posição geral do periódico, comandado pelo empresário e jornalista Mario Filho. Em um momento em que as personalidades da política de esportes no Brasil transitavam pelas posições opinativas daquele jornal, de considerável projeção na cidade do Rio de Janeiro, Lins do Rego exercia as funções tanto de cronista quanto de dirigente da Confederação Brasileira de Desportos (CBD). Este dado biográfico permite elucidar parte do teor de suas crônicas e explica seu entusiasmo com, pelo menos, três aspectos do torneio: a construção de um estádio público na capital da República; o brio e o orgulho nacional com a capacidade de realização do Mundial de 1950; e o apoio incondicional à performance dos jogadores da Seleção Brasileira, mesmo após a inesperada derrota para os uruguaios.
\end{abstract}

Palavras-Chave: Copa de 1950; Crônica esportiva; José Lins do Rego; Maracanã.

ABSTRACT: The article revisits the meaning of the 1950 FIFA World Cup for Brazil, in light of a series of sports chronicles by the writer José Lins do Rego, published in the Jornal dos Sports, between 1946 and 1950. The argument aims to show the assumptions and motivations that led the novelist from Paraíba to engage, through his daily column "Esporte e Vida" (Sport and Life), in the campaign for the 1950 FIFA World Cup. Such engagement was far from an isolated stance and it shared the general position of the newspaper, led by the businessman and journalist Mario Filho. At a time when personalities from sports politics in Brazil were going through the opinionated positions from that newspaper, of considerable projection in the city of Rio de Janeiro, Lins do Rego exercised the functions of both chronicler and leader of the Brazilian Sports Confederation (CBD). This biographical datum elucidates part of his chronicles and explains his enthusiasm with at least three aspects of the tournament: the construction of a public stadium in the capital of the Republic; the panache and national pride with the ability to execute the 1950 World Cup; and the unconditional support to the performance of the players of the Brazil national football team, even after the unexpected defeat to the Uruguayans.

KEYWORDS: 1950 FIFA World Cup; Sports chronicle; José Lins do Rego; Maracanã. 


\section{INTRODUÇÃo}

Bem-aventurados os que não são cronistas esportivos, pois não carecem de explicar o inexplicável e racionalizar a loucura.

Carlos Drummond de Andrade.

Da crônica esportiva depende muito o êxito da Copa do Mundo.

José Lins do Rego.

A construção do Maracanã e a realização da Copa do Mundo de 1950 têm sido objeto de uma série de pesquisas acadêmicas nos últimos anos, ${ }^{1}$ além de alvo de interesse do memorialismo esportivo e do mercado editorial brasileiro. A vigésima edição do Mundial, disputada no Brasil em 2014 e anunciada pela FIFA no ano de 2007, acentuou ainda mais a atenção dos pesquisadores, em virtude da repetição do evento no país, suscitando comparações e remissões entre as duas edições, distantes 64 anos no tempo.

Não obstante, cumpre reconhecer que o interesse pelo torneio de 1950 é anterior ao megaevento de 2014 e uma produção substantiva se acumulava desde a segunda metade do século XX. As circunstâncias da derrota brasileira na partida decisiva foram um dos principais motivos para tanto, com a extrapolação do significado de um resultado em princípio meramente esportivo para seu extravasamento em torno das características culturais, sociais e políticas mais amplas da sociedade e do Estado brasileiro.

É como se a expressão de um ritual "bom para pensar", empregada pelos antropólogos, pudesse ser aplicada à experiência da derrota da Seleção naquela ocasião. 0 malogro das expectativas em 1950 parece ter tido um efeito maior do que futuras vitórias e conquistas, responsáveis por projetar em âmbito internacional o chamado "país do futebol".

\footnotetext{
${ }^{1}$ FREITAS Jr.. No meio do caminho; PACHECO. Memórias da tragédia: masculinidade e envelhecimento na Copa do Mundo de 1950; BANCHETTI. Memórias em jogo; ALMEIDA. De Copa a Copa; SILVA JUNIOR. Maracanã, in memoriam; CLEMENTE. Maracanã.
} 
O presente artigo pretende contribuir à fortuna crítica universitária e jornalística acumulada sobre o IV Mundial da FIFA, realizado no Brasil, através de um ponto de vista peculiar. Trata-se da visão de um escritor brasileiro, consagrado pela geração do modernismo e do moderno regionalismo nordestino, durante as décadas de 1920 e 1930: José Lins do Rego. ${ }^{2}$ O romancista paraibano, radicado no Rio de Janeiro a partir de 1935 e aí estabelecido até 1957, ano de seu falecimento, vai, segundo seu próprio testemunho, "descobrir" o fenômeno do futebol durante o transcorrer da Copa de $1938 .^{3}$

Essa data marca a terceira edição da Copa da FIFA, na França, que teve transmissão radiofônica ao vivo e galvanizou a população brasileira, mobilizada a assistir ao desempenho do selecionado brasileiro em campo. A terceira posição no Mundial é bem-vista pela opinião pública, que destaca as virtudes dos atletas negros, capazes de encantar também os jornalistas franceses. Em 1938, os torcedores elegem o atacante Leônidas da Silva, artilheiro do torneio, um de seus principais ídolos da Seleção.

De acordo ainda com o relato de José Lins do Rego, a comoção nacional com o esporte brasileiro naquele evento seria decisiva na sua conversão ao futebol e, em especial, ao Clube de Regatas do Flamengo, no qual atuava Leônidas da Silva. A sinonímia entre o atleta e o seu clube constitui, na construção de seu discurso, a base para sua adesão entusiástica ao universo futebolístico.

Ao longo da década de 1940, a identificação com os esportes se consolidará e levará até a Lins do Rego assumir cargos na política esportiva e na vida clubista. ${ }^{4}$ Torna-se membro do CND - Conselho Nacional de Desportos e da Confederação Brasileira de Desportos - CBD. 5

Além da política esportiva, José Lins do Rego foi convidado por Mário Filho a colaborar no Jornal dos Sports. A colaboração diária, na coluna intitulada "Esporte e Vida", inicia-se no ano de 1945 e se estende a 1957, quando vem a falecer. Mais

\footnotetext{
${ }^{2}$ HOLLANDA. O descobrimento do futebol.

${ }^{3}$ MACHADO. Bola na rede e povo nas ruas!.

${ }^{4}$ CAPRARO et al.. A crônica esportiva de José Lins do Rego, p. 326.

${ }^{5}$ CND é um órgão estatal criado por Getúlio Vargas em 1941. CBD é uma entidade privada, surgida nos anos 1910, com estreitos vínculos junto ao poder político da primeira metade do século XX. Para uma história político-institucional da CBD/CBF, ver SARMENTO. A construção da nação canarinho.
} 
de mil e quinhentas crônicas são publicadas no decorrer desses doze anos. Seus escritos tinham curta extensão, variavam entre 10 e 15 linhas, e tratavam de temas variados da cena futebolística, com comentários de circunstâncias dos jogos e dos campeonatos, dos atletas e dos torcedores. Sua predileção pelo Flamengo era explícita, o que lhe valia uma série de provocações clubistas, a favor e contra a sua postura indisfarçada de um cronista rubro-negro, ${ }^{6}$ e colocava em dúvida a própria condição "especializada" do gênero da crônica esportiva. ${ }^{7}$

Para o presente artigo, vamos nos ater aos seus textos publicados no decorrer dos preparativos e da realização da Copa do Mundo de 1950. São escritos de conjuntura, redigidos, por assim dizer, no "calor da hora",8 capazes de dar elementos contemporâneos para reconstituir as polêmicas e os debates em torno da efeméride. 0 argumento proposto é o de que Lins do Rego, a despeito de suas opiniões expressas de maneira muito própria, endossava a posição política do jornal de Mário Filho. Esta se declarava notoriamente favorável ao torneio, em contraponto às críticas ao Mundial protagonizadas por outros periódicos e periodistas, como a Tribuna da Imprensa e o então vereador Carlos Lacerda.

Se José Lins do Rego era uma referência literária na capital da República nos idos de 1940 e 1950, seu prestígio na literatura repercutia em convites para colaborar nas colunas diárias dos principais jornais de então. Mais do que um acento subjetivo, sua crônica salientava uma "missão", 9 isto é, o compromisso público e coletivo do literato para com a sociedade e com o mundo à sua volta. 0 sentido missionário acompanha parte considerável dos intelectuais brasileiros da primeira metade do século XX. Desde a Primeira República, com Lima Barreto e Euclides da Cunha, a construção da nacionalidade era entendida como uma tarefa para os escritores.

Esse traço se acentua com a eclosão do movimento modernista na década de 1920 e suas diversas vertentes estético-política em busca da definição de uma brasilidade autêntica nos anos 1930 e 1940. A tarefa missionária pode ser

\footnotetext{
${ }^{6}$ BRAUNER. Entre as quatro linhas.

${ }^{7}$ CAPRARO. Identidades imaginadas, p. 203.

${ }^{8}$ GALVÃO. No calor da hora.

${ }^{9}$ Essa expressão, utilizada no título do artigo, faz alusão ao livro seminal de Nicolau Sevcenko, Literatura como missão: tensões sociais e criação cultural na Primeira República.
} 
emblematizada nos escritos, nas viagens de "descobrimento" e nas atuações públicas de Mário de Andrade, um dos mais importantes artífices do projeto artístico do modernismo. Ainda nos anos 1940, o caráter de "missão" influencia também os folcloristas do período, a exemplo de Câmara Cascudo, Renato Almeida e Cecília Meireles, conforme notável estudo do antropólogo Luís Rodolfo Vilhena, ${ }^{10}$ dispostos a salvaguardar a tradição material e cultural produzida no interior do país.

Assim, imbuído desse espírito de missão almejado por José Lins do Rego, que se volta para o universo específico do futebol, selecionamos um corpus com cerca de oitenta crônicas do escritor dedicadas à Copa de 1950. As publicações compreendem um período de cinco anos, entre o de 1946, quando é anunciada a escolha do Brasil como país-sede, e o de 1950, quando a competição é disputada. Nesse intervalo de tempo, o autor acompanha com entusiasmo o processo de erguimento do Maracanã, estádio municipal, exigência principal da FIFA para a realização do torneio, e comenta fatos, personagens e acontecimentos cotidianos relativos à preparação para os jogos.

Para tanto, estruturamos o artigo em três partes. A primeira constitui uma revisão bibliográfica centrada em dissertações e teses na área de História, que se dedicaram a examinar o significado do torneio para o Brasil em 1950 à luz dos relatos da imprensa.

A segunda seção, por seu turno, volta-se ao debate mais geral travado pelo escritor acerca os preparativos do Mundial, em particular toda a mobilização e discussão de governo e sociedade para o soerguimento de uma praça de esportes na capital da República.

Por fim, a terceira e última parte centra-se nas partidas futebolísticas propriamente ditas, em especial na performance dos jogadores da Seleção ao longo dos meses de junho e julho daquele ano, avaliando a reação do cronista ante a debacle para os uruguaios.

Para que esses objetivos fossem atingidos, lançou-se mão da pesquisa com fontes jornalísticas, mais precisamente da consulta seriada ao Jornal dos Sports, no setor de Periódicos da Fundação Biblioteca Nacional. 0 recorte de leitura do jornal

\footnotetext{
${ }^{10}$ VILHENA. Projeto e missão.
} 
cobriu um período de cinco anos, entre 1946 e 1950, com a contextualização do cotidiano da cidade e com o foco centrado nos escritos da coluna "Esporte e Vida", publicada quase diariamente pelo romancista, enquadrada no conjunto do jornal, em meio a suas manchetes, reportagens e demais crônicas.

Ao fim e ao cabo, procurou-se mostrar a peculiaridade da perspectiva de José Lins do Rego, articulada a uma visão ufanista mais abrangente que mobilizou um setor específico das classes dirigentes e dos segmentos políticos letrados brasileiros durante as décadas de 1940 e 1950. A característica do engajamento do romancista enfatiza a missão de uma crônica esportiva que acentuasse as demonstrações de capacidade de um povo "civilizado", simbolizado nas figuras dos jogadores e dos torcedores, e de um Estado "moderno", encarnado nos engenheiros construtores do Maracanã e nas autoridades governamentais à frente da organização daquele evento de magnitude internacional.

\section{REVISÃO DA LITERATURA SOBRE A COPA DE 1950 E A CRÔNICA ESPORTIVA}

A produção acadêmica dedicada à quarta edição do Mundial de 1950 inicia-se ${ }^{11}$ junto à própria constituição de um subcampo de pesquisas sobre a história, a antropologia e a sociologia do futebol no Brasil. Este processo se deu em princípios dos anos 1980 e um de seus marcos inaugurais é a coletânea Universo do futebol, organizada pelo antropólogo Roberto DaMatta. O livro inclui em seus capítulos ensaísticos uma análise antropológica da derrota brasileira na Copa do Mundo de 1950, tal como desenvolvida no ensaio de Arno Vogel, "O momento feliz: reflexões sobre o futebol e o ethos nacional" (1982).

No ensaio, Vogel vale-se dos discursos da imprensa para examinar os valores de fracasso e vergonha, bem como os de vexame, honra e status, que o autor aponta como herança longínqua da cultura mediterrânica, com influência no mundo ibérico e latino. Tais valores foram revividos nos apontamentos do

\footnotetext{
${ }^{11}$ É sempre difícil postular um marco zero para o estudo de determinado tema. O jornalista Mário Filho, embora não seja uma referência acadêmica, redigiu em sua segunda edição do livro O negro no futebol brasileiro um arrazoado sobre a importância da Copa de 1950 na constituição da identidade nacional.
} 
jornalismo esportivo, de modo a caracterizar a derrota e a reverberar por parte expressiva da sociedade brasileira, após a perda para o Uruguai.

A suposta ideia de "tragédia", quando referida a 1950, é vista por Arno Vogel como um conjunto de discursos que encenam um drama coletivo, seguido por um ritual funerário e por uma tristeza mortuária que lhe é correspondente. Não obstante, na sequência do argumento do autor, ressaltam-se a contraposição e a superação simbólica com a vitória da seleção brasileira na Copa de 1970, quando a população expia o episódio de vinte anos atrás e, de maneira diametralmente oposta, comemora o feito nacional no México de modo apoteótico e carnavalesco.

Se a Antropologia Social é responsável pela primeira aproximação interpretativa com o tema, a salientar a importância da memória, do imaginário e do simbólico na constituição das sociedades contemporâneas, a História, por sua vez, ingressaria no assunto em fins dos anos 1990. Pode-se considerar um marco importante para a historiografia a dissertação de mestrado de Gisella de Araújo Moura, intitulada O Rio corre para o Maracanã. ${ }^{12}$ O trabalho, defendido no programa de História Social da UFRJ, é publicado em livro no ano de 1998, quando da realização da Copa do Mundo da França, ocasião em que a seleção nacional voltaria a ser vice-campeã no torneio.

É possível afirmar que o estudo de Moura se tornaria modelar na abordagem historiográfica daquele evento esportivo, considerado chave no "complexo processo de construção do futebol como símbolo de uma identidade brasileira".13 A publicação ensejaria um modelo metodológico para muitas investigações posteriores nessa área. A razão para tanto é o modo pelo qual a historiadora reconstitui a chamada tristeza coletiva e o processo que culminaria com a decepção ocorrida no dia 16 de julho de 1950, interpretada como metáfora da derrota, extensível, por sua vez, a toda a nação brasileira.

A reconstituição do evento esportivo é feita com base nos referenciais teóricos de Norbert Elias e de Michael Pollak, assim como de Jacques Le Goff e de Pierre Nora, valendo-se do debate contemporâneo acerca do processo civilizador,

12 A autora, evidentemente, não estava só e sua pesquisa dialogou com publicações jornalísticas dedicadas a "exumar" os acontecimentos do Maracanazo, tais como Anatomia de uma derrota, de Paulo Perdigão, e Dossiê 50, de Geneton Moraes Neto.

${ }^{13}$ GUIMARÃES. Futebol, sonho e decepção, p. 210. 
da memória coletiva e das representações sociais. A pesquisa se estrutura em uma argumentação temporal tripartite, que acompanha a cronologia dos preparativos, das partidas e do seu desfecho, com a partida "fatal". A estruturação ternária permite contextualizar o Brasil do pós-Segunda Guerra Mundial e fazer um acompanhamento cerrado com as narrativas jornalísticas, a fim de repisar os passos de seu enredo, seguido pela cristalização final de um significado.

Ao contrário do que costuma acontecer nas peças de ficção, o desenlace do torneio, na narração da imprensa, é destituído de um "final feliz". A situação adversa gera por sua vez a desilusão e a perplexidade. Identifica-se o descompasso entre a euforia das expectativas e a realidade inelutável da dinâmica esportiva. Além disto, a situação inusitada quebra a crença de uma superioridade do país, supostamente advinda de uma técnica em campo capaz de ser traduzida em um resultado positivo, que propiciaria a comunhão e a exaltação nacional.

A frustração com a perda do campeonato internacional leva a uma revisão dos pressupostos em que se baseava a autorrepresentação da nação, dando margem a uma discussão mais ampla em torno das responsabilidades dos atores jogadores, treinadores e dirigentes -, mas também a uma reflexão mais aguda em torno dos fundamentos da formação social brasileira, tal como os cronistas a interpretavam e assimilavam naquela conjuntura de meados do século XX.

O estudo de Gisella de Araújo Moura foi seguido nas décadas posteriores por diversas investigações acadêmicas nas áreas de Ciências Sociais, Comunicação e Letras. Concentrando-nos nas pesquisas da área de História Social, pode-se dizer que muitas delas seguiram procedimentos semelhantes, cujo modelo deriva e amplia o método de trabalho de Moura, a lidar com as fontes e com os discursos jornalísticos, a exemplo das crônicas de Gustavo Corção na Tribuna da Imprensa, de Geraldo Romualdo da Silva no Jornal dos Sports, de Augusto Frederico Schmitt no Correio da Manhã, de David Nasser em O Cruzeiro ou ainda de Alfaiate no vespertino A Noite.

A problemática das narrativas jornalísticas na construção de sentido e de valor dos esportes para a nação é tratada em perspectiva análoga por Gérson Fraga, que em 2009 defendeu a tese de doutorado A derrota do 'Jeca' na imprensa brasileira: nacionalismo, civilização e futebol na Copa do Mundo de 1950. 0 trabalho 
foi desenvolvido no programa de pós-graduação em história da Universidade Federal do Rio Grande do Sul e publicado em livro no ano de 2014, nos meses que antecederam a Copa novamente realizada no Brasil.

A investigação examina a prática do futebol como instrumento de afirmação da nacionalidade e o paradoxo de um jornalismo que se via diante da necessidade de "explicar" ou de "justificar" a derrota, por parte de seus articulistas e repórteres. Isto se dava ante todas as expectativas em direção contrária, quais sejam, de vitória e de triunfo esportivo. A alternância entre heroísmo e vilania remonta, segundo o autor, a modelos culturais preestabelecidos no imaginário nacional, em princípios do século XX.

0 projeto civilizador à brasileira teve assim de lidar com tipos atrasados ou inferiores, ao modo daqueles encarnados nos personagens literários do Jeca Tatu e de Policarpo Quaresma, de princípios do século XX, que se supunham superados. A derrota de 1950 foi mais um momento em que tal quadro de inferioridade e atraso foi reavivado, desta feita com personificação nos futebolistas do selecionado nacional, a fazer as vezes de bode expiatório perante a sociedade.

Outro historiador que se dedica a reconstituir os passos jornalísticos da Copa de 1950 é Miguel Archanjo de Freitas Júnior, em tese de doutoramento defendida no mesmo ano de Gérson Fraga, em 2009. Defendido no departamento de História da Universidade Federal do Paraná, com mais de trezentas laudas, o texto apresentou o título de No meio do caminho - tensões presentes nas representações sobre o futebol e o ideal de modernidade brasileira na década de 1950.

À diferença de Moura e Fraga, contudo, o autor dilata seu olhar para todo o decênio de 1950, de modo a cotejar a experiência do selecionado nacional de 1950 com os desempenhos da Seleção nas Copas de 1954 e 1958, na Suíça e na Suécia, respectivamente. Não obstante, a fonte jornalística utilizada pelo pesquisador lança mão do Jornal dos Sports e do projeto esportivo de modernização encampado por Mário Filho, em meio à redemocratização e ao desenvolvimentismo por que passa a modernidade brasileira de meados do século passado.

À luz dos agentes futebolísticos, o historiador examina aspectos centrais do chamado "caráter nacional" brasileiro, num projeto que apresenta a face de uma modernidade sempre inconclusa, a exemplo dos regionalismos que dividem o eixo 
Rio-São Paulo e que se traduzem na rivalidade esportiva entre cariocas e paulistas. Freitas Júnior investiga também os alcances e limites do racismo no Brasil, a partir de debates internacionais como o Projeto Unesco, e discorre ainda sobre aquilo que denomina de "cultura da desculpa" no futebol brasileiro.

Para completar o breve levantamento, cabe, por fim, apontar dois trabalhos interessantes do ponto de vista historiográfico porquanto procuram descentralizar o olhar produzido sobre a Copa de 1950 e seu interesse, por assim dizer, monotemático em torno do Maracanã, dos jogos disputados no Rio de Janeiro, dos periódicos cariocas e/ou da partida final do Mundial perdida pela seleção brasileira para o selecionado uruguaio.

Referimo-nos, primeiramente, ao artigo dos historiadores Euclides Couto e Marcus Vinícius Lage, cujo título é: "Representações do nacionalismo em tempos de Copa do Mundo: um estudo sobre a 'grande imprensa' mineira (1949-1950)". Ainda que a temática permaneça voltada ao entendimento da autoimagem de nação projetada pelo futebol, os autores do texto dedicam-se à fonte Estado de Minas, jornal de propriedade de Assis Chateaubriand, pertencente à cadeia de imprensa dos Diários Associados, para analisar como tal discurso reverberava em capitais importantes do país, a exemplo de Belo Horizonte.

Dentre a série de textos explorados, destaca-se no artigo, entre outros, as colunas "O campeonato mundial em foco" e "Conhecendo o esporte no Velho Mundo", esta última de autoria dos jornalistas Mario Provenzano e Fernando Bruce. Diga-se, também, que a capital mineira se valeu de um estádio recémconstruído no centro belo-horizontino, o Independência, vinculado ao clube Sete de Setembro, para se tornar uma das seis cidades-sede da Copa de 1950. Couto e Lage observam ainda que havia a expectativa do jornal local da presença de até 50 mil turistas em Minas Gerais, atraídos pela competição.

O segundo artigo tem o igual mérito de contribuir para o descentramento do debate sobre o Mundial em torno da Seleção Brasileira, do Rio de Janeiro e do Maracanã. Trata-se de "Copa do Mundo de 1950: a imprensa e os jogos realizados em Curitiba", escrito por uma equipe de pesquisadores da Universidade Federal do Paraná. 0 texto analisa o discurso patriótico e civilizatório subjacente aos relatos dos periodistas sobre o evento esportivo e sobre o comportamento da população curitibana. 
O propósito dos autores é contextualizar os preparativos, a promoção e as repercussões nos editoriais dos jornais, em particular na Gazeta do Povo, acerca das duas partidas ocorridas no estádio Durval de Brito - Espanha X Estados Unidos e Suécia X Paraguai -, situado na capital paranaense.

\section{OS PREPARATIVOS PARA A COPA E A CONSTRUÇÃo do MARACANÃ NA COLUNA “ESPORTE E VIDA" DO JORNAL DOS SPORTS}

Feita a revisão da literatura, vamos acompanhar doravante, nesta e na próxima seção, o conjunto das crônicas esportivas de José Lins do Rego dedicadas ao Mundial de 1950. Trata-se de um total de 80 selecionadas, publicadas ao longo de cinco anos, embora mais concentradas no bimestre de junho e julho de 1950, em particular durante as três semanas de realização do torneio.

Nesta parte, será enfocada a preparação para a disputa do torneio, tal como descrita pelo cronista do Jornal dos Sports. As publicações se estendem entre junho de 1946, quando o congresso da FIFA anuncia, em Luxemburgo, a escolha do Brasil como país-sede, com a presença do representante brasileiro da CBD, Luiz Aranha, até junho de 1950, momento em que o Estádio Municipal, principal palco da Copa, é inaugurado.

No ano de 1946, data quadrienal que, em princípio, deveria abrigar mais uma edição do Mundial, impedida de ocorrer em face da Segunda Guerra, apenas 4 crônicas de José Lins do Rego vão ser dedicadas ao tema. Em junho, o cronista reconhecia que "o mundo que surgiu depois é bem outro", em alusão ao conflito bélico que deixara a Europa sob escombros, o que obstava a concretização do torneio para aquele ano. Em julho, voltava a dar notícias em duas ocasiões da reunião da FIFA e da previsão inicial da entidade, que estimava o evento para o ano de 1949.

Já em setembro de 1946, o tom da crônica evidencia o ânimo do escritor, para não dizer seu entusiasmo, pois relatava a decisão de Jules Rimet, presidente da entidade, de realizar a Copa do Mundo no Brasil. Para tanto, segundo Lins do Rego, este logro era resultado da capacidade de persuasão de Luiz Aranha, presidente da CBD, conhecido pelo apelido de Lulu. Em grau ainda maior de intimidade, referia-se ao dirigente como a "sereia Lulu", assim referido por seu poder encantatório: “O velho Rimet não sabia que aqui pelos trópicos há sereias de 
um metro e oitenta e, se não cantam em tom de ópera de Paris, sabem de coisas que os europeus não sabem".14

Esses comentários eram emitidos na coluna do escritor, denominada "Esporte e Vida", que, como se sabe, comportava uma miscelânea de temas esportivos. Dentre os assuntos de que se ocupava o cronista estavam o campeonato carioca, seus dirigentes, jogadores, polêmicas e partidas, com especial destaque para o Clube de Regatas do Flamengo. Nesse período, pouco a pouco, as atenções do autor vão concentrar-se na organização da Copa. As informações versam sobre os personagens da FIFA, as autoridades da CBD, os selecionados de cada país, o treinamento da seleção brasileira, as expectativas da população com o torneio, entre outros tópicos.

O dado, ao ser observado no corpo do jornal, evidencia que o evento não constituía um interesse próprio ou exclusivo do autor, mas uma demanda estratégica da política editorial do periódico, com a qual o cronista se alinhava. Junto ao temário geral, a partir do ano de 1947 o conjunto dos cronistas do Jornal dos Sports volta seu interesse mais diretamente para tecer comentários sobre o Mundial. Conforme as palavras do pesquisador André Couto, o alinhamento assim se dava:

A engenharia civil empregada na construção do estádio do Maracanã seria alvo de cotidianas matérias e crônicas no $J S$ no final da década de 1940. 0 concreto e o cimento, a urbanização, a capacidade de organizar um grande evento seriam símbolos do ideário modernizador que o esporte poderia criar na conjuntura de virada de década. E o $J S$, liderado por seu proprietário e editor, Mário Filho, soube aproveitar este momento para empreender esta importante campanha para fins próprios, ou seja, incrementar os seus negócios à frente do jornal.15

A temática central no triênio 1947, 1948 e 1949, sempre que Lins do Rego volve à Copa, é sem dúvida a construção de um estádio municipal, que viria mais tarde a ser conhecido pela população como Maracanã. Já em meados de 1947 o debate político sobre a criação de uma praça de esportes pública mobilizava o cronista. Com efeito, o número de crônicas salta de quatro, em 1946, para dezoito, no ano seguinte.

\footnotetext{
14 JORNAL DOS SPORTS. O campeonato continua, p. 5.

${ }^{15}$ COUTO. Cronistas esportivos em campo, p. 59.
} 
O motivo para o crescimento no número de crônicas é a encampação de um projeto que seria importante não apenas para a realização do torneio, pois a construção de um estádio à altura da magnitude do evento era a principal exigência da FIFA. Em especial, tal empreendimento seria também um legado em potencial, responsável por contribuir para o crescimento do futebol brasileiro e para o incremento de arrecadação dos principais clubes da capital da República.

Convém frisar que se tratava de um período marcado pelo fim do ciclo ditatorial do país, pós-Estado Novo (1937-1945), com a aprovação de uma nova constituição, em 1946, e com a eleição de um novo presidente, Eurico Gaspar Dutra, eleito com 55\% dos votos. ${ }^{16} 0$ ex-ministro da guerra de Getúlio Vargas, por seu turno, indica o nome do prefeito do Distrito Federal, o general Ângelo Mendes de Morais, à administração da cidade na segunda metade da década de 1940, em sucessão a Hildebrando de Góis.

Em crônica de 11 de junho de 1947, intitulada “0 estádio municipal e o general Mendes de Moraes", Lins do Rego comenta o processo sucessório na prefeitura do Rio e sua importância para a competição:

Sai o Sr. Hildebrando de Góis, que estava cheio de boas intenções, homem capaz de muito fazer, como demonstrou em ano e meio de administração, e vem para substituí-lo o general Mendes de Moraes que, em Juiz de Fora, já se manifestava amigo entusiasta de nossa praça de esportes. E por que não acreditar na obra essencial à cidade? ${ }^{17}$

Se a importância do presidente da CBD, Mário Pollo, é inconteste na organização do evento, a prefeitura do Rio de Janeiro ganhava em protagonismo nas crônicas, pois era a responsável por viabilizar a praça de esportes. A própria ideia inicial de um estádio nacional é revista e passa-se a associar a alcunha de Estádio Municipal. José Lins referia-se, assim, aos "olhos fixos" no prefeito, para o soerguimento da praça.

Em paralelo às publicações no Jornal dos Sports, José Lins do Rego, na condição de dirigente da $\mathrm{CBD}$, concedeu entrevista ao jornal $O$ Globo, sendo publicada apenas algumas semanas antes que o general Mendes de Moraes

\footnotetext{
${ }^{16}$ VIEIRA. A República brasileira, 1951-2010, p. 94.

${ }^{17}$ JORNAL DOS SPORTS. O estádio municipal e o general Mendes de Moraes, p. 3.
} 
assumisse o cargo de prefeito do Distrito Federal. Nela, quando questionado sobre qual seria sua sugestão para a resolução do impasse do estádio, o escritor aconselha “[...] que se inventassem no Rio um Prestes Maia”, em referência ao prefeito de São Paulo na época de inauguração do estádio do Pacaembu, entregue em 1940.

0 prefeito, por seu turno, atuaria em conjunto com João Lyra Filho, jurista que na época ocupava cargo estratégico na prefeitura: "Na Secretaria de Finanças, há um homem capaz de pôr em execução um plano financeiro à altura dos acontecimentos. Acredito no prefeito e acredito em Lyra Filho".18

Sendo ele próprio um homem dos desportos, responsável pela formulação do CND em 1941, Lyra Filho teve a responsabilidade de gerir a secretaria de fazenda do município no período de construção do estádio. Cuidou, para tanto, da organização do torneio na cidade, desde a delimitação do terreno que seria utilizado para erguer a praça de esportes até a definição dos custos que permitiriam a sua viabilização, passando pela negociação da aprovação do equipamento esportivo junto à Câmara de Vereadores, onde teve de ser sabatinado pelos representantes municipais.

Na supracitada entrevista, ainda, o escritor ressalta que a CBD não é capaz de viabilizar a construção do referido estádio e alude a uma suposta situação de penúria. Aventa uma reforma no estádio de São Januário como mecanismo, em última instância, capaz de remediar o imbróglio. Cético, o dirigente levanta dúvidas acerca da atuação governamental para que o projeto saísse do papel, declarando que "[...] entre a promessa dos candidatos e a realidade dos fatos vai um mundo",19 embora demonstrasse aparente confiança na palavra do presidente Dutra, caso o mesmo procedesse com uma promessa nesse sentido.

Esses, por sua vez, mostraram-se divididos em torno do assunto. Entre 1947 e 1948, até o lançamento da pedra fundamental, a política local encarnou posições favoráveis à Copa, como Ary Barroso, e posições contrárias, como Tito Lívio e Carlos Lacerda, que criticavam os gastos com futebol, especialmente para a construção de estádios. Estes, segundo eles, eram de inspiração arquitetônica fascista. Defendiam, em contrapartida, um equipamento esportivo situado na

\footnotetext{
18 JORNAL DOS SPORTS. O prefeito e o estádio, p. 3.

19 JORNAL DOS SPORTS. Uma carta de fã, p. 3.
} 
periferia do Rio, na zona oeste, mais precisamente em Jacarepaguá. 0 acalorado debate ocorreu na câmara municipal da cidade, ainda que ambos, Ary Barroso e Carlos Lacerda, fossem vereadores do mesmo partido, a UDN.

Na sua coluna, Lins do Rego, por seu turno, contemporizava a "loucura" de Lacerda e procurava dissuadir o polemista com o argumento de que: "[...] o Estádio Municipal é coisa que se quer para este século e o sonho de Jacarepaguá é assim como a capital do Brasil no Planalto Central de Goiás". ${ }^{20}$ Dizia ainda que a Câmara Municipal, responsável por chancelar o projeto do estádio, transformara-se num covil dos leões, onde reinavam os "furiosos amigos do povo". Não obstante, para cada "golpe de Lacerda" havia um "contragolpe de Lyra Filho".

Ao longo desse período, pois, o estádio foi o cerne do interesse das crônicas de Lins do Rego, que assumiu desde o primeiro momento o ponto de vista dos favoráveis ao projeto. Contrapôs-se aos que especulavam que o bairro da Gávea poderia ser um bom local para o estádio e contra-argumentava os representantes do Vasco da Gama, que consideravam ser suficientes as reformas de São Januário: "[...] o que precisa a cidade é do próprio estádio, onde não mande o interesse de um clube. Onde só prevaleça o interesse do povo".21

Em 1948, a construção é aprovada e sua pedra fundamental é lançada. As crônicas passam a assumir um tom ufanista, institucional e patriótico de apoio ao seu soerguimento, com a vitória do "estádio do povo". Nas páginas do Jornal dos Sports, a defesa coletiva do estádio público proporcionou lemas como "a batalha do Derby", alusão ao local em que seria construído o futuro Maracanã, na zona norte da cidade, cuja obra Lins do Rego acompanha e inspeciona com entusiasmo até 1950.

No início de 1949, por exemplo, o cronista começa o ano com menções à "grande vitória", depois de uma visita ao Maracanã: "Vi o Estádio Municipal e, para ser franco, espantei-me... os que não acreditavam na obra que apareçam no Derby, abram os olhos e que não lhes caiam os queixos...".22

Pouco depois, em abril, o assunto volta à baila, como se Lins do Rego continuasse a mesma crônica:

\footnotetext{
${ }^{20}$ JORNAL DOS SPORTS. O mal de Lacerda, p. 3.

21 JORNAL DOS SPORTS. O estádio municipal, p. 3.

${ }^{22}$ JORNAL DOS SPORTS. A grande vitória, p. 3.
} 
Vi-os todos de queixos caídos. Tive medo de deslocamentos maxilares. Eram os delegados sul-americanos diante da ciclópica realização do Estádio Municipal. Eu mesmo, que lá não punha os pés há dois meses, vi um mundo novo... Detalhe a detalhe, quase que bloco a bloco, e o imenso Estádio aparece já de fisionomia declarada. Voltei do almoço de confraternização continental, acreditando mais no brasileiro. ${ }^{23}$

A um ano de realização do certame, em junho de 1949, o estádio volta a ser tema da coluna do escritor. Ao comentar a visita da delegação do Arsenal da Inglaterra, clube londrino que excursionava pelo Brasil, diz o escritor:

Não vi os ingleses de queixo caído, mas os vi de boca aberta... o Estádio Municipal parece já o colosso que será. As formas de madeira, pilastras de cimento, as imensas alegrias, tudo mesmo para provocar aquele espanto dos britânicos. Carlito Rocha me dizia: Seu Zelins, diante disto eu me sinto mais brasileiro. Esta obra me orgulha, me faz acreditar no Brasil. As obras do estádio demonstram de fato a capacidade dos nossos engenheiros e administradores. ${ }^{24}$

O elogio à administração será endereçado tanto ao general prefeito Mendes de Morais, que se tornava um "benemérito dos esportes" pela dedicação ao estádio, quanto ao general presidente Eurico Gaspar Dutra. 0 autor dizia que a CBD contava com a presidência do país para atender aos "pesadíssimos encargos" 25 demandados pela Copa do Mundo.

Afora isso, uma ou outra informação sobre as eliminatórias na Europa é comentada, como o local de disputa da partida entre Espanha e Portugal. Outro comentário sobre o torneio diz respeito à disputa entre os dirigentes dos clubes do Rio de Janeiro e de São Paulo na indicação dos jogadores que comporão o elenco da Seleção, um traço recorrente em edições anteriores do Mundial, 1930, 1934 e 1938.

Uma das querelas comentadas por Lins do Rego é aquela travada entre o atacante do Botafogo, Heleno de Freitas, e o técnico da Seleção, o "disciplinador" Flávio Costa, que fora soldado da Polícia Especial, órgão criado pelo general

\footnotetext{
23 JORNAL DOS SPORTS. O grande estádio, p. 9.

24 JORNAL DOS SPORTS. O estádio e os ingleses, p. 5.

25 JORNAL DOS SPORTS. Contamos com o presidente Dutra, p. 5.
} 
Zenóbio da Costa durante a ditadura do Estado Novo. ${ }^{26} \mathrm{~A}$ despeito dos apelos do cronista em favor de Heleno, "um grande do nosso football", ${ }^{27}$ o treinador não o convoca. Em sentido oposto, no entanto, José Lins do Rego apoia a decisão de Flávio Costa pela não escalação do zagueiro Píndaro, do Fluminense, que é desligado do selecionado.

A opinião do escritor sobre a organização do torneio não era apenas a de mais um colunista. Desde 1947, segundo o jornal $O$ Globo, ${ }^{28}$ além de romancista consagrado, José Lins do Rego ocupa o cargo de secretário-geral da CBD, posição importante na hierarquia da entidade. Neste sentido, suas crônicas internalizam os conflitos da entidade com os cartolas da Asociación del Fútbol Argentino. No início do ano de realização da competição, a AFA anuncia sua desistência de participação nas eliminatórias.

A retirada é uma forma de retaliação ao país-sede, cuja rivalidade se acentuara no decorrer dos anos 1940, em competições como a Copa Roca e o Campeonato Sul-Americano. Ademais, a Argentina pleiteara hospedar o torneio e a escolha da FIFA em favor do Brasil desagradara os portenhos. Tal atitude retaliativa será muito criticada por Lins do Rego, que a considerava como as "futricas" do país vizinho contra a Copa do Mundo. O boicote dos argentinos foi seguido de uma campanha de descrédito do Mundial promovido pela imprensa daquele país, conforme observava o escritor na crônica "Que se danem". 29

No início do mês seguinte, o cronista de "Esporte e Vida" voltava a comentar as críticas da Argentina e defendia a Copa em tom entusiástico: "Devemos ficar tranquilos e não nos alarmar com alaridos desta natureza. Aqui se realizará o Campeonato do Mundo, no maior estádio do mundo, na mais bela cidade do mundo". ${ }^{30}$

Em maio, mês que antecede o início do torneio, as crônicas sobre a competição crescem em termos quantitativos. Lins do Rego tece comentários elogiosos sobre o estádio, já preparado para abrigar o Mundial, e se volta para aspectos técnicos e táticos do elenco brasileiro. Jogos preparatórios da Seleção são

\footnotetext{
${ }^{26}$ COUTINHO. Zé Lins, Flamengo até morrer, p. 293.

27 JORNAL DOS SPORTS. O caso Heleno, p. 5.

${ }^{28} \mathrm{O}$ GLOBO. $2^{\mathrm{a}}$ seção da edição vespertina, p. 1.

29 JORNAL DOS SPORTS. Que se danem, p. 9.

30 JORNAL DOS SPORTS. O campeonato do mundo, p. 5.
} 
comentados, em especial duas partidas contra o Uruguai: a primeira no Pacaembu, quando da derrota do Brasil por 4 a 3, e a segunda em São Januário, ocasião em que a equipe nacional vence por 3 a 2. Dentre os atletas uruguaios, chama-lhe a atenção o "colored Andrade", que na crônica intitulada "Não estou prosa" o escritor reputa como "a maior figura entre todos". 31

\section{OS SOLDADOS DA SELEÇÃO: ESPORTE, POLÍTICA E SOCIEDADE NO MUNDIAL DE 1950}

A última seção deste artigo focaliza os meses de realização da Copa, que transcorre em um espaço de três semanas, entre 24 de junho e 16 de julho. A competição se dá na presença de treze selecionados nacionais, sendo sete do continente americano Bolívia, Brasil, Chile, Estados Unidos, México, Paraguai e Uruguai - e seis da Europa - Espanha, Inglaterra, Itália, Iugoslávia, Suécia e Suíça. Em razão de uma série de desistências, a exemplo de França, Escócia e Portugal, as dezesseis vagas do torneio não são preenchidas. Como palco, seis são as cidades-sede: Belo Horizonte, Curitiba, Porto Alegre, Recife, Rio de Janeiro e São Paulo.

O bimestre junho-julho concentra a quase totalidade das atenções da coluna "Esporte e Vida" no evento esportivo internacional. São ao todo 35 crônicas dedicadas ao torneio, sendo dezessete em junho e dezoito em julho, praticamente a metade do total de crônicas selecionadas de um conjunto de cinco anos de publicações sobre o assunto.

À poucas semanas do início, chama a atenção o olhar ampliado do escritor sobre o torneio. Longe de autocentrar-se na capital da República, a seis de junho, José Lins publica crônica "O esforço do Sport Club Recife", em que comenta sua viagem a Pernambuco e a constatação de que “[...] a Copa do Mundo está empolgando os nordestinos". A observação claramente denota sua tentativa de cunhar uma imagem positiva, ao transformar Recife em metonímia para todo o Nordeste. A visita ao estádio pernambucano responsável por abrigar as partidas

\footnotetext{
${ }^{31}$ JORNAL DOS SPORTS. Não estou prosa, p. 5.
} 
vale ainda um comentário de sua parte: "Fui ao campo do Sport Club e fiquei encantado com o esforço para pôr em bom estado o seu campo". ${ }^{32}$

A contagem regressiva se instaura. A pouco mais de dez dias para o começo da Copa, o autor relata sua confiança na equipe treinada por Flávio Costa e não deixa de ponderar as vaias dos torcedores a um treino no Maracanã: "[...] o homem da arquibancada sabe valorizar o que é bom, mas sofre de sofreguidão, e desespera-se com facilidade". ${ }^{33}$ Em um dos treinamentos, no entanto, Lins do Rego dá razão aos apupos, tendo em vista que a seleção enfrenta a equipe do Flamengo, o clube de sua predileção. Em "Não tem culpa os operários", o escritor condena os dirigentes que escolheram o time carioca para duelar com a Seleção e justifica a preferência dos presentes: "Não devemos brincar com a paixão das massas". ${ }^{34}$

Cioso dos preparativos, o colunista comenta a utilização das instalações do Clube Ginástico Português como base para a organização do torneio pela CBD, tecendo elogios à "boa gente lusa". ${ }^{35}$ Em 16 de junho, uma semana antes do início, ocorre a solenidade de inauguração do Maracanã. Para a abertura, realiza-se a partida entre o selecionado mineiro e carioca, com o jovem Didi a fazer o primeiro gol no estádio. 0 autor se compraz em afirmar e vaticinar: "Aí está o Estádio Municipal no seu dia maior. De pé, a maravilha. É o orgulho de nossa cidade. E será o palco da vitória do Brasil na Copa do Mundo". 36

Chega o dia da abertura da Copa. Em um domingo, o Maracanã assiste à vitória da Seleção brasileira na estreia contra o México, com goleada de 4 a 0 . No dia seguinte, 25, Lins do Rego publica uma crônica sobre a transformação da cidade para o recebimento da disputa internacional. Para tal, ressalta a mobilização de toda a população e o ambiente festivo que toma conta da capital da República:

A cidade mudou de cara com a "Copa do Mundo". Por toda a parte se vê uma mudança de fisionomia. As bandeiras desfraldadas, e por toda parte a ansiedade pelo acontecimento. 0 Rio se entregou de corpo e alma aos visitantes que aqui chegaram, para ver de perto uma autêntica maravilha da natureza. O Rio não esconde um pedaço de mar, um

\footnotetext{
32 JORNAL DOS SPORTS. O esforço do Sport Club Recife, p. 5.

${ }^{33}$ JORNAL DOS SPORTS. O homem das arquibancadas, p. 5.

34 JORNAL DOS SPORTS. Não têm culpa os operários, p. 9.

35 JORNAL DOS SPORTS. Os amigos do Ginástico, p. 5.

${ }^{36}$ JORNAL DOS SPORTS. O estádio, p. 9.
} 
recanto de floresta, uma nesga do céu. A cidade se preparou com suas melhores festas, aí está bonita como nunca. ${ }^{37}$

Poucos dias depois da estreia, a Seleção viaja a São Paulo para a partida contra a Suíça, no Pacaembu. O cronista assiste ao jogo, ao lado do editor José de Barros Martins. Este, como boa parte da torcida paulista, mostra-se irritado com o desempenho da equipe e com o técnico Flávio Costa, especialmente em virtude da não escalação de atletas do estado de São Paulo no elenco titular. 0 empate contra os suíços em 2 a 2 é a centelha para uma saraivada de vaias. José Lins acompanha com certo tom irônico o comportamento hostil dos paulistanos no estádio e observa que "[...] Martins bufava com um ódio e uma fúria de dragão das cavernas". ${ }^{38}$

Em comparação com o Maracanã, que recebera mais de oitenta mil espectadores, o Pacaembu presencia apenas metade do público carioca. Em razão da diferença de capacidade, bem como da postura hostil dos torcedores paulistanos, a CBD decide realizar os demais jogos da Seleção na capital da República. Depois do empate, a partida seguinte é decisiva para a continuidade do Brasil no torneio.

Devido ao caráter eliminatório, no dia 01 de julho José Lins publica a crônica "Agora ou nunca", em referência à disputa contra a Iugoslávia, acentuando a convicção de que, apesar das adversidades, seria possível superar a "valentia dos filhos de Tito". 39 A população comparece em número massivo e mais de 150 mil torcedores testemunham a vitória de 2 a 0 do Brasil. Com gols de Ademir e Zizinho, o selecionado avança no campeonato.

Em sua coluna, o escritor não comenta apenas os jogos nacionais, voltandose por exemplo para a partida que ocorre no Maracanã no dia seguinte ao Brasil X Iugoslávia. Domingo, 02 de julho, é dia do enfrentamento entre Espanha e Inglaterra. Ao contrário do favoritismo inicial, os ingleses perdem para os espanhóis, cuja "fúria" é a virtude mais decantada por José Lins. Do alto de seu ardor patriótico, o romancista indispõe-se com a imprensa internacional, em particular com o periódico esportivo francês L'Équipe, que faz críticas acerbas à

\footnotetext{
37 JORNAL DOS SPORTS. A cidade, p. 11.

38 JORNAL DOS SPORTS. A cólera de Martins Editor, p. 7.

39 JORNAL DOS SPORTS. Agora ou nunca, p. 5.
} 
organização do torneio. Em resposta, o cronista chama o jornal estrangeiro de "língua de trapo".40

Depois de eliminar a Inglaterra, a Espanha passa a ser o adversário mais difícil para o Brasil e a equipe mais cotada para o quadrangular final da Copa, integrado ainda por Suécia e Uruguai. No domingo, 09 de julho, a Seleção inicia a decisão em jogo contra os suecos. José Lins procura demonstrar cautela nos dias que antecedem a disputa e alerta para a importância de seguir a moral da humildade nos confrontos esportivos, de modo a evitar o excesso de confiança e a "máscara". Afinal, a Suécia derrotara e eliminara a Itália em pleno Pacaembu lotado de imigrantes italianos que, mesmo radicados no Brasil, demonstraram seu fervor pelo país de origem.

A vitória triunfal de 7 a 1, diante de mais de 140 mil espectadores, gera um clima de euforia em torno da equipe. 0 goleador Ademir, autor de quatro gols, é um dos mais festejados. Na sequência, começam os preparativos para o embate contra a agora favorita Espanha. Assim como indispôs-se contra os jornalistas esportivos franceses, o colunista troca farpas com a imprensa de Madri que insiste em criticar a FIFA e a CBD, fazendo uma "campanha injusta".41

Depois de provocações mútuas, o resultado em campo é amplamente favorável ao Brasil, com nova goleada, desta feita pelo placar de 6 X 1 . Assistido por mais de 150 mil torcedores, o resultado desata um clima ainda mais eufórico entre os brasileiros, ante a iminência de conquista do título. Os adversários supostamente mais fortes haviam sido superados e bastava um empate contra $o$ Uruguai no dia 16 para a ansiada conquista.

Ao longo da semana, a coluna "Esporte e Vida" adota uma postura de cautela e respeito, ainda que um frisson tome conta de dirigentes, jornalistas e torcedores em geral. A demanda pelo contato com os atletas faz com que a CBD mude o local da concentração da Seleção que, hospedada em uma mansão isolada no bairro de São Conrado, transfere-se para as dependências do estádio de São Januário, nas proximidades do Maracanã, em meio ao burburinho dos fãs e ao assédio da imprensa e dos políticos dos mais diferentes matizes.

\footnotetext{
40 JORNAL DOS SPORTS. Uma língua de trapo, p. 5.

${ }^{41}$ JORNAL DOS SPORTS. Uma campanha injusta, p. 5.
} 
O escritor adverte: "Teremos amanhã os homens da camisa celeste. São adversários duríssimos, homens de cabelo na venta, gente disposta a tudo e já muito experimentada em disputas internacionais. Rapazes da Seleção, aos uruguaios! Os orientais são os mais perigosos". ${ }^{42}$

No domingo, dia da última e decisiva partida, entre Brasil e Uruguai as expectativas atingem o seu ápice. A crônica "Hoje" refere-se à batalha final e concita a equipe à vitória, sem descurar da cautela verbal típica da retórica moral esportiva e sempre prezada por Lins do Rego. Assim, o respeito ao adversário e a valorização de suas qualidades são enaltecidas:

Os nossos grandes adversários, na disputa desta "Copa do Mundo", teriam que ser mesmo os uruguaios. E aí estão eles, para a última batalha. Por duas vezes, este ano, tivemos que nos empenhar, para vencê-los por score mínimo. Pensar em uruguaios é ter a certeza de que há sempre adversário duro a combater. 0 peito dos homens da "Celeste" é peito de combatentes valorosos. E além de peito têm classe bastante para serem, como são, campeões do mundo, como já foram, por duas vezes. Rapazes do Brasil, não vacilem um instante sequer. A "Celeste" sabe combater como autênticos bravos. Vamos vencer estes bravos. ${ }^{43}$

Sem embargo, para surpresa, frustração e consternação geral, diante de um público de 173.850 pagantes, a ansiada conquista não é alcançada, com a vitória de virada da seleção uruguaia no Maracanã. Dois dias após a inesperada derrota para o Uruguai na partida final, na terça-feira do dia 18 de julho, José Lins do Rego publica a crônica "A derrota", em que analisa de forma ambígua o significado do jogo para a compreensão do Brasil. Nela, é possível também perceber questões mais amplas sobre a decepção gerada pelo desempenho dos futebolistas brasileiros:

Vi um povo de cabeça baixa, de lágrimas nos olhos, sem fala, abandonar o Estádio Municipal como se voltasse do enterro de um pai muito amado. Vi um povo derrotado, e mais que derrotado, sem esperança. Aquilo me doeu no coração. Toda a vibração dos minutos iniciais da partida reduzidos a uma pobre cinza de um fogo apagado. E, de repente, chegou-me a decepção maior, a ideia fixa que se grudou na minha cabeça, a ideia de que éramos mesmo um povo sem sorte, um povo sem as grandes alegrias das vitórias, sempre perseguido pelo azar, pela

\footnotetext{
${ }^{42}$ JORNAL DOS SPORTS. Agora os mais duros, p. 5.

${ }^{43}$ JORNAL DOS SPORTS. Hoje, p. 9.
} 
mesquinharia do destino. A vil tristeza de Camões, a vil tristeza dos que nada têm que esperar, seria assim o alimento podre dos nossos corações. Não dormi, senti-me, alta noite, como que mergulhado num pesadelo. E não era pesadelo, era a terrível realidade da derrota. ${ }^{44}$

Tempos depois, o autor amadureceria aquela experiência e voltaria ao tema, por meio de um pequeno ensaio, com o sugestivo título de "O caráter do brasileiro":

A Copa do Mundo, que se acabou tão melancolicamente, deu-me a impressão de uma experiência amarga, capaz de completar as minhas observações sobre o caráter do nosso povo.

Vimos, no Estádio do Maracanã, uma multidão como raramente se tem aglomerado, em manifestações coletivas, no Brasil. Vimos duzentas mil pessoas comprimidas numa praça de esportes, nas reações mais diversas, ora na gritaria das ovações, no barulho das vaias ou no angustioso silêncio da expectativa de um fracasso. Ali estava todo o povo brasileiro, uma média de homens e mulheres de todas as classes sociais. Não era o Brasil de um grupo, de uma região, de uma classe. Não. Era o Brasil em corpo inteiro.

Para o observador social, para os que têm o poder de revelar o que há de mais particular nos povos, o campo era o mais propício. Mas para mim as observações começaram antes dos jogos sensacionais. Tive a oportunidade, como dirigente, de travar conhecimento, mais íntimo, com os que procuravam as acomodações, com os que tinham parcela de mando, com os que se sentiam com o direito de crítica, e mais ainda, com a lama das sarjetas, que queria passar pela água mais lustral deste mundo. E me perguntará o leitor: que impressão lhe deixou o brasileiro? Boa ou má?

Eu diria, sem medo de cair no exagero: uma boa impressão. Senti que havia povo na Nação - uma nova gente com capacidade de se congregar para uma causa, para uma obra, para os sofrimentos de um fracasso. Fizemos um estádio ciclópico, em menos de dois anos; organizamos um campeonato mundial, o de mais ordem até hoje realizado; formamos uma equipe quase perfeita de futebol. E, quando o título nos fugiu das mãos, soubemos perder, dando aos turbulentos sul-americanos uma lição de ética esportiva. ${ }^{45}$

Não obstante, após a ideia fixa que tanto crispou o cronista José Lins do Rego - somos mesmo um povo desgraçado, tristemente vil, sem sorte, desventurado -, o ensaísta José Lins do Rego fazia um balanço positivo da Copa do Mundo que decorria da postura patriótica dos torcedores. Em um momento

\footnotetext{
${ }^{44}$ REGO. O caráter do brasileiro, p. 125.

${ }^{45}$ REGO. O caráter do brasileiro, p. 208-210.
} 
fundamental de afirmação do país, o povo brasileiro havia dado uma lição de ética esportiva: saber perder.

Ante aquela experiência amarga, ante aquela "tristeza brasileira" de que falava a tradição do pensamento social, a ressurgir na história como mais um drama coletivo e a ter como consequência imediata o recrudescimento do discurso do racismo - com a atribuição da culpa da derrota aos jogadores negros Barbosa, Juvenal e Bigode ${ }^{46}$, conforme a versão consagrada na segunda edição de $O$ negro no futebol brasileiro (1964), do jornalista Mário Filho -, Lins do Rego acentuava uma demonstração de maturidade da população.

A crônica da tristeza brasileira, que já havia sido tratada no modernismo pelo historiador Paulo Prado, ${ }^{47}$ em seu ensaio de 1928, Retrato do Brasil, era agora revista por José Lins do Rego. A visão do autor de Menino de engenho, entretanto, sublinhava de forma afirmativa a ideia de povo e de nação. 0 estádio era tido como a síntese desse mesmo povo e de onde poderia se tirar um retrato em corpo inteiro do Brasil. Mais do que uma sede para competições, mais do que uma mera praça de esportes, o estádio de futebol era o lugar apropriado para a observação social do "caráter brasileiro".

Finda a Copa, o escritor ainda comentaria os efeitos daquele torneio para o Brasil. Em parte, voltar-se-ia à defesa dos jogadores derrotados, especialmente os mais acusados, como Barbosa, Bigode e Juvenal. Defenderia com ardor o lateral Bigode, que teria se acovardado ante um suposto tapa do capitão uruguaio Obdúbio Varela. Apesar de suas "três infelizes jogadas", 48 o escritor saía em defesa do atleta que representava seu clube do coração: "Vai hoje o Flamengo voltar ao campo do Maracanã para mostrar que o football não morreu no Brasil"49.

Meses depois de construído o Maracanã, José Lins do Rego voltaria a exaltar as qualidades da arquitetura moderna brasileira no processo de construção da nova sede náutica do Flamengo, projetada por Oscar Niemeyer, arquiteto que na década de 1950 se notabilizaria junto com o urbanista, arquiteto e historiador

\footnotetext{
${ }^{46}$ RODRIGUES FILHO. O negro no futebol brasileiro, p. 289.

${ }^{47}$ PRADO. Retrato do Brasil, p. 243.

48 JORNAL DOS SPORTS. Bigode e a torcida flamenga, p. 5.

49 JORNAL DOS SPORTS. O Flamengo volta, p. 5.
} 
modernista Lúcio Costa pela construção da cidade de Brasília. Em crônica de 31 de agosto de 1950, José Lins do Rego assim se refere ao projeto de Niemeyer:

Vi ontem os planos de Niemeyer para as novas instalações da sede náutica do Flamengo. E posso dizer que vi uma obra-prima de criação arquitetônica. Obra de um mestre, tocado da melhor qualidade poética. A imaginação de Niemeyer aproveitou-se de um lindo recanto da natureza carioca para efeitos que são de encher a vista. Se os homens do Flamengo tiverem juízo, não vacilarão. E, desde logo, passariam para o chão das margens da lagoa a concepção de Niemeyer. E posso garantir que irá a cidade do Rio de Janeiro possuir a mais bela, a mais pitoresca, a mais humana sede esportiva. É só haver no Flamengo gente de miolo na cabeça e coragem de agir.50

Dessa forma, ao acentuar o que nos dias de hoje se chamaria de "legado" do Mundial de 1950 - uma infraestrutura de equipamentos esportivos cujo símbolo principal era o Maracanã, capaz de multiplicar de maneira exponencial a arrecadação dos clubes cariocas - Lins do Rego construía, por meio de suas crônicas, um discurso positivo e nacionalista sobre o desempenho brasileiro, dentro e fora de campo. Partícipe da organização da Copa, sua coluna servia de apoio à posição do Jornal dos Sports e do seu proprietário, Mário Filho, defensores incondicionais da realização do evento internacional no Brasil.

\section{CoNCLUSÃo}

A trajetória de José Lins do Rego contém uma faceta menos conhecida. Ela compreende o homem de letras que se volta à política dos desportos, à crônica sendo esta herdeira do folhetim francês - e em particular à crônica esportiva. No presente artigo, tratou-se de explorar não o romancista do ciclo açucareiro nordestino, mas o cronista urbano, cuja importância advém do fato de ser previamente um escritor reconhecido, vinculado a círculos importantes da literatura brasileira, que se volta à crônica sobre esportes em determinado momento de sua vida no Rio de Janeiro.

\footnotetext{
${ }^{50}$ REGO. O caráter do brasileiro, p. 126.
} 
A carreira de José Lins do Rego na passagem do romance à crônica e, em seu caso particular, para a crônica esportiva, revela-se exemplar nesse sentido. Ligado no início de sua carreira jornalística, durante a década de 1920 em Pernambuco e Alagoas, à polêmica literária e ao panfleto político, veio a aflorar em José Lins do Rego no início da década de 1930 a vocação literária de romancista.

Com uma obra serial e opulenta, os romances de José Lins do Rego compreendiam todo um painel histórico da região nordestina, todo um retrato psicológico de seus tipos sociais mais característicos e todo um quadro político, econômico e cultural. Ao longo dos anos de 1930, eles foram dando corpo ficcional à maior parte do "Ciclo da Cana-de-Açúcar" e do "Ciclo do Misticismo, do Cangaço e da Seca".

Além da recepção crítica abonadora de membros da Academia Brasileira de Letras e do acolhimento editorial de José Olympio, durante décadas editor de ponta no país, a publicação ininterrupta de seus romances fez extrapolar os limites provincianos do romancista paraibano e, ainda na década de 1930, transfere-se de maneira definitiva para o Rio de Janeiro.

É no Rio de Janeiro das décadas de 1940 e 1950 que a publicação das obras ficcionais do escritor paraibano torna-se menos intensa e mais intermitente, dando margem ao reaparecimento da figura de José Lins do Rego como cronista e possibilitando o surgimento de uma nova faceta de sua personalidade: a de cronista esportivo.

Se o autor já exercia a atividade de colunista nos principais jornais de Recife e de Maceió nas décadas de 1920 e 1930, esse ofício volta a se ampliar no Rio de Janeiro, onde chega a colaborar regularmente em três periódicos da cidade, dentre eles $O$ Globo, 0 Jornal, Jornal dos Sports, além da revista $O$ Cruzeiro e da crônica radiofônica diária.

Discorrendo sobre os mais diversos assuntos, como a poesia e a pintura, o cinema e a música, a história e a política, o cronista registrava também em sua tradicional coluna dos Diários Associados, "Conversa de lotação”, suas impressões sobre o cotidiano do habitante da cidade, não deixando nunca de cultuar um estilo simples, franco e despojado, sem sofisticações gramaticais e sem artifícios de linguagem. 
Frente ao homem de gabinete, típico do bacharelismo, a crônica de José Lins do Rego fazia emergir o homem de rua, tão cultuado pelo modernismo. E, em contraposição ao romance marcado pela atmosfera da introspecção psicológica e da decadência social, a sua crônica afirmava o envolvimento com a cidade, com a vida coletiva e com o tempo presente, em seus aspectos mais prosaicos, circunstanciais e comezinhos.

José Lins do Rego foi assim tornando-se, pouco a pouco, um homem dos desportos. Embora a sua atuação não tenha sido concebida de antemão, a inserção no universo esportivo e sua rede de sociabilidade na capital da República levaramno à ocupação de cargos nas principais entidades representativas do futebol. À maneira de outro modernista, o poeta, editor e amigo Augusto Frederico Schmidt, que dirigiu o Botafogo, José Lins do Rego esteve à frente da direção do Clube de Regatas do Flamengo entre 1939 e 1944.

Ao longo do presente artigo, procurou-se enfatizar o tom de ufanismo grandiloquência do discurso ético esportivo de José Lins do Rego em sua coluna "Esporte e Vida", dedicada a abordar a Copa de 1950. A grandiosidade do seu discurso estaria presente em José Lins do Rego desde no final da década de 1940, quando, por exemplo, se empenha na campanha pelo soerguimento do Estádio Municipal, o Maracanã. O esforço na construção do estádio e na realização da Copa do Mundo de 1950 vai mobilizar todo um apelo ufanista para o feito da arquitetura moderna brasileira e para o exemplo dos jogadores em campo, encarnando as vicissitudes, as qualidades e os defeitos do povo.

Em vez de pactuar com a "cultura da desculpa" 51 após a perda do título, Lins do Rego assumiu um tom assertivo em suas crônicas, salientando o conjunto das virtudes do torcedor e do jogador brasileiro, metonímia do próprio Brasil. Procuramos mostrar que parte dessa assertividade se deveu à posição geral do periódico de Mário Filho, um dos grandes patrocinadores da Taça do Mundo no Brasil. Na mesma proporção, seu posicionamento proativo deve ser compreendido na chave de sua colocação institucional, porquanto, em fins dos anos 1940, o escritor ocupava o posto de secretário-geral da Confederação Brasileira de Desportos.

\footnotetext{
${ }^{51}$ FREITAS Jr.. Copa do Mundo de 1950, p. 118.
} 
O famoso literato não se singularizou dessa maneira por um determinado estilo literário aplicado à visão do futebol, mas por uma espécie de militância cronística, em que cumpria ao homem de letras a defesa de um lídimo nacionalismo, capaz de afirmar as virtudes patrióticas, que se mostravam, entre outros, por meio do futebol. Ao contrário da estetização operada por um Nelson Rodrigues, conforme sugere a pesquisadora Natasha Santos,52 José Lins do Rego rotinizou suas crônicas ao comentar o dia a dia do futebol carioca e brasileiro de meados do século XX.

Imbuído de uma "missão", na condição de portador de um sentido construtivo para a afirmação identitária nacional, valeu-se nessa série de quase uma centena de crônicas para acompanhar a rotina dos preparativos e dos jogos do Mundial. Mostrou-se assim um artífice na construção do significado da Copa do Mundo FIFA do ano de 1950.

\section{REFERÊNCIAS}

ALMEIDA, Rosângela de Sena. De Copa a Copa: memórias do estádio de futebol do Maracanã. Tese (Doutorado em Memória Social) - UNI-Rio, Rio de Janeiro, 2014.

BANCHETTI, Luciano Deppa. Memórias em jogo: futebol, seleção brasileira e as Copas do Mundo de 1950 e 1954. Dissertação (Mestrado em História Social) - PUC-Rio, São Paulo, 2011.

BRAUNER, Eugênio. Entre as quatro linhas: da crônica sobre o futebol ao colunismo esportivo ou da profissionalização do futebol e do cronista. Dissertação (Mestrado em Literatura Brasileira) - UFRGS, Porto Alegre, 2010.

CAPRARO, André Mendes. Identidades imaginadas: futebol e nação na crônica esportiva brasileira do século XX. Tese (Doutorado em História) UFPR, Curitiba, 2007.

CAPRARO, André Mendes (et.al.). A crônica esportiva de José Lins do Rego: política, paixão e relações de força. Revista Brasileira de Educação Física e do Esporte, São Paulo, v. 30, n. 2, p. 323-333, jun. 2016.

CAPRARO, André Mendes (et.al.). Copa do Mundo de 1950: a imprensa e os jogos realizados em Curitiba. Esporte e Sociedade, Rio de Janeiro, n. 14, mar.-jun. 2010.

\footnotetext{
${ }^{52}$ SANTOS. O futebol em Nelson Rodrigues, p. 106.
} 
CLEMENTE, Rafael William. Maracanã: espaço e representação entre torcedores de futebol. Dissertação (Mestrado em Ciências Sociais) - UFRRJ, Rio de Janeiro, 2016.

COUTINHO, Edilberto. Zélins, Flamengo até morrer! Rio de Janeiro: s.e., 1995.

COUTO, André Alexandre Guimarães. Cronistas esportivos em campo: letras, imprensa e cultura no Jornal dos Sports. Tese (Doutorado em História) UFPR, Curitiba, 2016.

COUTO, Euclides; LAGE, Marcus Vinícius Costa. Representações do nacionalismo em tempos de Copa do Mundo: um estudo sobre a 'grande imprensa' mineira (1949). Revista Recorde, Rio de Janeiro, v. 9, n. 1, p. 1-7, jun. 2016.

FRAGA, Gérson Wasen. A "derrota do Jeca" na imprensa brasileira: nacionalismo, civilização e futebol na Copa do Mundo de 1950. Tese (Doutorado em História) - UFRGS, Porto Alegre, 2009.

FREITAS JR., Miguel Archanjo. No meio do caminho: tensões presentes nas representações sobre o futebol e o ideal de modernidade brasileira na década de 1950. Tese (Doutorado em História) - UFPR, Curitiba, 2009.

FREITAS JR., Miguel Archanjo. Copa do Mundo de 1950: a cultura da desculpa como justificativa de um fracasso. In: FREITAS JR., M. A.; CAPRARO, A. (Org.). Passe de letra: crônica esportiva e sociedade brasileira. Ponta Grossa: Editora Vila Velha, 2012.

GALVÃO, Walnice Nogueira. No calor da hora: a guerra de Canudos nos jornais. São Paulo: Editora Ática, 1974.

GUIMARÃES, Manuel Salgado. Futebol, sonho e decepção. Revista Estudos Históricos, Rio de Janeiro, v. 13, n. 23, p. 209-213, jul. 1999.

HOLLANDA, Bernardo Borges Buarque de. O descobrimento do futebol: modernismo, regionalismo e paixão esportiva em José Lins do Rego. Rio de Janeiro: Edições Biblioteca Nacional, 2004.

Jornal dos Sports, Rio de Janeiro, 1946-1950 [Seleção].

MACHADO, Felipe Morelli. Bola na rede e povo nas ruas! Estado Novo, imprensa esportiva e torcedores na Copa do Mundo de 1938. Dissertação (Mestrado em História) - PUC-Rio, São Paulo, 2011.

MOURA, Gisella de Araújo. O Rio corre para o Maracanã. Rio de Janeiro: Editora FGV, 1998.

O Globo, Rio de Janeiro, 09 maio 1947, 2ª seção da edição vespertina, p. 1.

PACHECO, Leonardo Turchi. Memórias da tragédia: masculinidade e envelhecimento na Copa do Mundo de 1950. Revista Brasileira de Ciência do Esporte, Florianópolis, v. 32, n. 1, p. 25-40, nov. 2010.

PRADO, Prado. Retrato do Brasil - ensaio sobre a tristeza brasileira. São Paulo: Companhia das Letras, 1997. 
REGO, José Lins do. O caráter do brasileiro. In: Flamengo é puro amor. Rio de Janeiro: José Olympio, 2002.

REGO, José Lins do. O caráter do brasileiro. In: O vulcão e a fonte. Rio de Janeiro: Edições O Cruzeiro, 1958.

RODRIGUES FILHO, Mário. O negro no futebol brasileiro. Rio de Janeiro: Editora Mauad, 2003.

SANTOS, Natasha. O futebol em Nelson Rodrigues: uma pesquisa historiográfica acerca de literatura e identidade nacional. In: FREITAS JR., M. A.; CAPRARO, A. (Org.). Passe de letra: crônica esportiva e sociedade brasileira. Ponta Grossa: Editora Vila Velha, 2012.

SARMENTO, Carlos Eduardo. A construção da nação canarinho: uma história institucional da seleção brasileira de futebol, 1914-1970. Rio de Janeiro: Editora FGV, 2013.

SEVCENKO, Nicolau. Literatura como missão: tensões sociais e criação cultural na Primeira República. São Paulo: Companhia das Letras, 2003.

SILVA JUNIOR, César Roberto de Lima. Maracanã, in memoriam. TCC (História, Memória e Patrimônio) - Universidade Cândido Mendes, Rio de Janeiro, 2014.

VIEIRA, Evaldo. A República brasileira, 1951-2010: de Getúlio a Lula. São Paulo: Editora Cortez, 2015.

VILHENA, Luís Rodolfo. Projeto e missão: o movimento folclórico brasileiro. Rio de Janeiro: Funarte/Fundação Getúlio Vargas, 1997.

VOGEL, Arno. O momento feliz: reflexões sobre o futebol e o ethos nacional. In: DaMATTA, R. (et. al.). Universo do futebol. Rio de Janeiro: Edições Pinakotheque, 1982. 